\title{
PEMBERIAN GELAR ADAT KEPADA KEPALA DAERAH DI KABUPATEN BUNGO: PROSES, STRUKTUR YANG MEMPENGARUHI DAN KENDALA
}

\author{
Iwan Ridwan \\ Universitas Muara Bungo \\ iwan09ukm@gmail.com \\ Mulia Jaya \\ Universitas Muara Bungo \\ Mulia_jaya@gmail.com \\ Een Siskawati Dewi \\ Bungo TV \\ een_dewi@gmail.com
}

\begin{abstract}
ABSTRAK
Kabupaten bungo yang di pimpin oleh bupati bungo Mashuri dan wakil bupati bungo Syafrudin Dwi Apriyanto juga di beri gelar oleh LAM-J kabupaten Bungo pada tahun 2016, gelar yang di berikan pada bupati bungo yaitu Datuk Putro Arif Bijaksono Setioardjo dan wakil bupati Datuk Pemangku Setio Mandaliko. Dari paparan latar diatas dapat ada beberapa merumuskan masalah dalam penelitian ini yatu bagaimana proses pemberian gelar adat kepada kepala daerah Kabupaten Bungo sebagai wujud kesepakatan sosial etnis melayu bungo?, struktur-struktur apa saja yang mempengaruhi dalam pemberian gelar adat kepada kepala daerah Kabupaten Bungo sebagai wujud kesepakatan sosial etnis melayu Bungo, apa saja kendala dalam pemberian gelar adat kepada kepala daerah Kabupaten Bungo sebagai wujud kesepakatan sosial etnis melayu Bungo? Penelitian ini akan dilaksanakan di Lembaga Adat Melayu Jambi Kabupaten Bungo. Mengenai Analis pemberian gelar adat kepada tokoh masyarakat oleh Lembaga Adat Melayu Jambi Kabupaten Bungo. Penelitian ini menggunakan metode penelitian kualitatif dengan cara melakukan pendekatan deskriptif. Hasil penelitian yaitu pemberian gelar adat kepada kepala daerah oleh Lembaga Adat Melayu Kabupaten Bungo, merupakan hasil Rapat Kerja Daerah (Rakerda), Pemberian gelar adat yang diberikan kepada kepala daerah merupakan hasil keputusan Rapat Kerja Daerah Lembaga Adat Melayu Kabupaten Bungo Nomor 01/LAD/2008 dan Nomor 12/KEP-LAM/2016, yang dituangkan dalam dalam program kerja tahunan,Surat Keputusan Lembaga Adat Melayu Kabupaten Bungo merupakan suatu kebijakan. Dasar pelaksanaan Pembentukan Panitia Pengukuhan Gelar Adat, yaitu berdasarkan Keputusan Bupati Bungo Nomor 485/BPMPD/Tahun 2009 tanggal 28 Desember 2009 tentang Pembentukan Panitia Pengukuhan Gelar Adat dan bekerjasama dengan Lembaga Adat Melayu Kab.Bungo. Strukturstruktur yang mempengaruhi dalam pemberian gelar adat kepada kepala daerah Kabupaten Bungo, sepenuhnya diurus oleh Lembaga Adat Melayu Kab.Bungo.Kendala-kendala Dalam Pelaksanaan Pemberian Gelar Adat yaitu kendala dalam proses ceremony atau pengukuhan karena financial, tidak adanya keikutsertaan seluruh anggota Lembaga Adat Melayu Kabupaten Bungo Dalam Perumusan
\end{abstract}


Gelar Adat, panduan atau pedoman pemberian gelar adat kepada kepala daerah belum di bukukan secara legal.

Kata Kunci : Pemberian, Gelar Adat, Kepala Daerah, Lembaga Adat

\begin{abstract}
Bungo regency led by Bungo regent Mashuri and Bungo deputy regent Syafrudin Dwi Apriyanto were also given the title by the Bungo regency LAM-J in 2016, a title given to the Bungo regent Datuk Putro Arif Bijaksono Setioardjo and vice regent Datuk Pemangku Setio Mandaliko. From the background explanation above, there can be some formulation of the problem in this research, how is the process of awarding customary titles to the Bungo District head as an expression of ethnic Malay social agreement? Bungo Malay ethnic social agreement, what are the obstacles in awarding the adat title to the Bungo District head as an expression of Bungo Malay ethnic social agreement? This research will be conducted at the Jambi Malay Customary Institution of Bungo Regency. Regarding Analyst awarding customary titles to community leaders by the Jambi Malay Customary Institution of Bungo Regency. This research uses qualitative research methods by means of a descriptive approach. The results of the study are the granting of a traditional title to the regional head by the Bungo Regency Malay Customary Institution, which is the result of the Regional Work Meeting (Rakerda). and Number 12 / KEP-LAM /2016, as outlined in the annual work program, the Decree of the Bungo Regency Malay Customary Institution is a policy. The basis for the implementation of the Establishment of a Traditional Title Inauguration Committee, based on the Bungo Regent Decree No. 485 / BPMPD / 2009 dated December 28, 2009 concerning the Establishment of a Traditional Title Inauguration Committee and in collaboration with the Malay Customary Institution of Bungo Regency. Structures that affect the awarding of a customary title to the regional head of the Bungo Regency, are fully managed by the Malay Customary Institution of Bandung Regency. Constraints in the Implementation of the Adat Title Award are obstacles in the process of ceremonies or inauguration due to financial, no participation of all members of the Customary Institution Bungo Regency in the Formulation of Customary Degrees, guidelines or guidelines for granting traditional titles to regional heads have not been legally recorded.
\end{abstract}

Keywords : Giving, Traditional Title, Regional Head, Traditional Institution

\title{
PENDAHULUAN
}

Indonesia merupakan Negara besar yang memiliki beragam suku bangsa, etnis, agama, tradisi, adat dan budaya. Tentunya hal ini merupakan bentuk kekayaan yang dimiliki dan yang dibanggakan oleh bangsa ini, tentunya disatu daerah akan mempunyai perbedaan dari daerah lain. Norma yang berlaku dalam hukum fositif itu lebih banyak terdapat norma hukum, etika, dan sosial. Begitu pula di kabupaten Bungo yang terletak di provinsi jambi, agar terciptanya kerukunan dan keamanan maka adanya aturan atau norma adat yang di naungi oleh Lembaga Adat Melayu Jambi (LAM-J) kabupaten Bungo. Di dalam LAM-J kabupaten Bungo ada adat yang memiliki peranan tersendiri seperti peranan adat dalam masyarakat kabupaten bungo. Sesungguhnya sejak zaman dahulu sampai sekarang, prikehidupan masyarakat, terutama di dusun daerah kabupaten Bungo, di tuntut oleh adat istiadat yang dipegang nenek mamak secara 
turun temurun dan di patuhi oleh penduduk yang berdiam dalam wilayah persekutuan Hukum Adat Bungo.

Adat istiadat tersebut tidak pernah bertentangan dengan peraturan-peraturan pemerintah, karena aturan nenek mamak selaku pemegang adat selalu ada kerjasama dan saling pengertian dengan pihak pemerintah. Karena itulah kita kenal seluko adat yang berbunyi (Buku Pedoman Adat Bungo, 2014:1) :

\section{Adat ditangan Nenek Mamak}

Undang ditangan Rajo (Pemerintah)

Sebagai penuntun prikehidupan dalam mencapai masyarakat adil dan makmur, bahagia lahir batin, maka di kenal pula seluko adat yang berbunyi :

Adat bersendi syarak, syarak bersendi khitabullah

Syarat mangato, adat memakai

Kedua seluko adat di atas memperlihatkan jalinan yang erat antara adat, agama dan aturan pemerintah. Demikian pula antara pimpinan adat, ulama dan pemerintah. Dalam bahasa adat, ikatan yang erat disebut :

\section{Tali nan bepintal tigo}

Lembaga adat merupakan suatu lembaga yang dibentuk oleh masyarakat adat itu sendiri, oleh karena itu kedudukan lembaga adat sangat strategis untuk menampung aspirasi anggota masyarakat adat maupun dalam proses penyelesaian sengketa antara anggota masyarakat adat maupun antara wilayah adat, maupun antara warga masyarakat adat dengan pemerintah dengan cara arif dan bijaksana dengan mempedomani norma adat bersendikan syarah dan kitabullah, serta aturan adat yang mengatur segala sendi kehidupan bermasyarakat. Lembaga Adat merupakan kegiatan sangat penting dalam kehidupan masyarakat, yang diatur oleh hukum berdasarkan kebudayaan manusia, Untuk itulah perlunya disusun aturan dalam rangka memberikan kerangka dasar terhadap tata upacara dari masing-masing peristiwa dalam daur kehidupan manusia. Kabupaten bungo yang di pimpin oleh bupati bungo Mashuri dan wakil bupati bungo Syafrudin Dwi Apriyanto juga di beri gelar oleh LAM-J kabupaten Bungo pada tahun 2016, gelar yang di berikan pada bupati bungo yaitu Datuk Putro Arif Bijaksono Setioardjo dan wakil bupati Datuk Pemangku Setio Mandaliko. 
Hal tersebut merupakan adat istiadat atau kebiasaan yang telah menjadi turun menurun. Karena setiap kepala daerah atau tokoh pemimpin di kabupaten bungo maka akan selalu diberi gelar adat sebagai wujud kesepakatan sosial etnis oleh LAM-J kabupaten Bungo. Dijelaskan gelar yang di dapat oleh kepala daerah tersebut merupakan keputusan bersama atas kesepakatan sosial melayu bungo berdasarkan SK-LAM JAMBI KABUPATEN BUNGO NOMOR:12/KEP-LAM/2016. Pemimpin atau kepala daerah yang di beri gelar juga atas berdasarkan seluko adat yang berbunyi :

Rumah nan betengganai

Kampong nan betuo

Luhak nan bepenghulu

Negeri nan bebatin

Rantau nan bejenang

Alam nan berajo

Yang memiliki arti :

Rumah di pimpin oleh tengganai

Kampong di pimpin oleh tuo-tuo atau datuk-datuk

Luhak dipimpin oleh penghulu

Negeri di pimpin oleh batin

Rantau di pimpin oleh jenang

Alam dipimpin oleh rajo

Tuo-tuo, datuk-datuk, penghulu, batin, jenang, rajo adalah penguasa atau kepala pemerintah dalam wilayahnya, dan sekaligus meupakan pimpinan adat. Namun pada masa pemerintahan colonial Belanda, maka segala bentuk jabatan serta gelar di hapuskan. Kemudian dalam tata susunan pemerintahan colonial Belanda tahun 1926 munculah kepala Marga. Kepala Marga diberi sebutan Pasriah. Pasriah selain sebagai kepala pemerintahan terendah juga sebagai selaku pemangku adat. Dikalangan pribumi, terutama suku Jawa terdapat gelar pribadi yang diberi izin oleh Gubernur atau Residen dan gelar resmi yang diberi oleh Gubernur Jendral. Gelar pribadi adalah panggilan Raden Mas, sampai perkariban keempat. Raden dari perkariban kelima sampai keenam, kemudian selanjutnya Mas. Gelar resmi adalah panggilan Adipati, ario dan tumenggung. Gelar resmi Tumenggung ini paling rendah, dan cukup hanya diberikan oleh Residen. Dalam pemberian Gelar pribadi, Residen meminta pertimbanagn kantor penasehat jendral pada zaman Belanda (pada masa itu) (Aqih, 1986:38). 
Dengan adanya undang-undang pemerintah desa, sudah tentu jabatan rangkap ( sebagai kepala pemerintahan dan sebagai pemimpin adat) tidak berlaku lagi. Namun adat terus berjalan, pimpinan adat beralih menjadi pimpinan non formal, dalam bentuk nenek mamak, dan Lembaga-lembaga Adat. Dalam adat bungo, seorang yang akan di angkat menjadi pimpinan adat jika memiliki 9 syarat sebagai berikut :

1. Berpengetahuan atau berilmu

2. Baligh berakal

3. Berbudi baik

4. Beragama islam

5. Dipilih oleh masyarakat adat

6. Sanggup mengisi adat

7. Menuang lumbago

8. Menurut pada negeri dan

9. Pancasila

Selain putra daerah bungo yang menjadi kepala daerah dan mendapat gelar oleh lembaga adat, presiden Susilo Bambang Yudhoyono menerima gelar adat Melayu Jambi, Sri Paduko Maharajo Notonegoro. Pengukuhan gelar ini dilakukan oleh Ketua Lembaga Adat Melayu (LAM) Hasip Kamaluddin Syam Adipati Agung Mangkunegoro di Balairung Lembaga Adat Melayu, Kota Jambi, Rabu (21/9) malam. Ibu Negara Hj. Ani Bambang Yudhoyono juga menerima penghargaan Karang Setio berupa liontin dan pakaian adat kebesaran. Pada prosesi pemberian gelar, Presiden SBY yang mengenakan baju adat berwarna kuning, dipasangkan keris dan selempang, serta merima surat pengukuhan. Gelar yang diberikan kepada Presiden SBY, memiliki arti pembesar utama diatas pembesar yang mengatur dan menertibkan penyelenggaraan negara. Memori masyarakat Jambi kepada SBY telah tertanam sejak memegang amanah sebagai Pangdam II Sriwijaya dengan pendekatan persuasif kultural dalam menjaga stabilitas hankam di wilayah Sumbagsel (Sumatera bagian selatan), serta besarnya perhatian beliau terhadap pentingnya adat istiadat dalam menjalani hidup dan kehidupan.

Presiden SBY dianggap tepat menerima gelar adat tersebut karena selama menjabat sebagai presiden telah mengunjungi bumi Jambi sebanyak dua kali, dan membuat perekonomian Jambi lebih maju. Dari segi keamanan pun terpelihara dengan baik. Selain itu 
Presiden SBY memiliki kedekatan emosional karena pernah menjabat sebagai Pangdam II Sriwijaya. Lembaga adat melayu Jambi kabupaten Bungo telah menjalankan adat istiadat dalam pemberian gelar sesuai dan dengan semestinya. Namun bagaimana agar masyarakat Jambi khusunya kabupaten muara Bungo mengetahui proses dalam pemberian gelar adat kepada kepala daerah kabupaten bungo sebagai wujud kesepakatan sosial etnis melayu bungo.

\section{Rumusan Masalah}

Dari paparan latar belakang diatas dapat diperhatikan dan dipahami. Hingga penulis dapat merumuskan masalah dalam penelitian adalah sebagai berikut :

1. Bagaimana proses pemberian gelar adat kepada kepala daerah Kabupaten Bungo sebagai wujud kesepakatan sosial etnis melayu bungo?

2. Struktur-struktur apa saja yang mempengaruhi dalam pemberian gelar adat kepada kepala daerah Kabupaten Bungo sebagai wujud kesepakatan sosial etnis melayu Bungo?

3. Apa saja kendala dalam pemberian gelar adat kepada kepala daerah Kabupaten Bungo sebagai wujud kesepakatan sosial etnis melayu Bungo ?

\section{Tujuan Penelitian}

Dalam penelitian ini hendaknya harus memiliki tujuan yang lebih jelas untuk dapat mengetahui apa yang sebenarnya terjadi dan serta apa yang sebenarnya dicari oleh penulis sehingga akan memberikan suatu arahan dan langkah- langkah yang nyata, sesuai dengan maksud dari penelitian ini. Untuk itu tujuan dari penelitian ini yaitu sebagai berikut :

1. Untuk mengetahui bagaimana proses pemberian gelar adat kepada kepala daerah Kabupaten Bungo sebagai wujud kesepakatan sosial etnis melayu bungo

2. Untuk mengetahui struktur-struktur apa saja yang mempengaruhi dalam pemberian gelar adat kepada kepala daerah Kabupaten Bungo sebagai wujud kesepakatan sosial etnis melayu Bungo.

3. Untuk mengetahui kendala apa saja dalam pemberian gelar adat kepada kepala daerah Kabupaten Bungo sebagai wujud kesepakatan sosial etnis melayu Bungo.

\section{Pengertian Gelar Adat}

Dalam masyarakat adat di Indonesia mengenal juga istilah Gelar Adat. Gelar ini diberikan oleh Ketua Adat setempat setelah memenuhi berbagai persyaratan tertentu. Setiap 
suku bangsa tentu mempunyai tata cara tersendiri yang khas dalam memberikannya. Hal ini tentunya menjadi warna tersendiri bagi keanekaragaman budaya di Indonesia.

Salah satu suku bangsa yang mempunyai kebiasaan memberikan gelar adat adalah Suku Lampung. Menurut Ali (dalam Haryadi, 2015) Ketua Adat Desa Pekurun Marga Selagai, Lampung Utara, pemberian gelar merupakan hal yang umum dilakukan terhadap masyarakat di desanya.

Adapun urutan pemberian Gelar Adat yang pertama adalah gelar "Tuan/Ratu/Raja", kedua gelar"Pangeran", ketiga gelar "Sunan" dan gelar yang paling tinggi adalah"Sultan." Menurut Dalom Edward Syah (dalam Yuniar 2015:3,) gelaran atau sebutan untuk menunjukkan kedudukan seseorang dan bagaimana cara untuk menghargainya. Menurut Seem R. Canggu, gelar adat menunjukkan tingkat kebangsawan dan kedudukan seseorang di dalam adat. Gelar dalam bahasa Jambi artinya nama. Dalam penelitian ini, gelar adat yang dimaksud adalah upacara pemberian nama adat pada saat menjadi kepala daerah atau pemimpin yang ada di kabupaten Bungo sebagai wujud kesepakatan sosial etnis melayu jambi atau LAM-jambi.

\section{Lembaga Adat}

Lembaga adat, merupakan suatu lembaga yang dibentuk oleh masyarakat adat itu sendiri, oleh karena itu kedudukan lembaga adat sangat strategis untuk menampung aspirasi anggota masyarakat adat maupun dalam proses penyelesaian sengketa antara anggota masyarakat adat maupun antara wilayah adat, maupun antara warga masyarakat adat dengan pemerintah dengan cara arif dan bijaksana dengan mempedomani norma adat bersendikan syarah dan kitabullah, serta aturan adat yang mengatur segala sendi kehidupan bermasyarakat (http://informasijambi.blogspot.com/2010/03/apa-itu-lembaga-adat.html).

\section{Kepala Daerah}

Negara Kesatuan Republik Indonesia dibagi atas daerah-daerah provinsi. Daerahdaerah provinsi tersebut dibagi lagi atas daerah kabupaten dan daerah kota. Setiap daerah provinsi mempunyai pemerintahan daerah yang diatur dengan peraturan perundang-undangan. Seluruh daerah tersebut dipimpin oleh kepala pemerintahan daerah yang disebut dengan kapala daerah. Kepala daerah dalam melaksanakan penyelenggaraan pemerintahan daerah dibantu oleh wakil kepala daerah. Kepala daerah adalah seorang yang diberikan amanah atau tugas oleh seorang pemerintah pusat untuk menjalankan suatu pemerintahan di daerah.

Berikut adalah contoh sebutan kepala daerah : 
1) Kepala daerah wilayah provinsi disebut gubernur.

2) Kepala daerah wilayah kabupaten disebut bupati.

3) Kepala daerah wilayah kota disebut wali kota.

Masa jabatan kepala daerah adalah selama 5 tahun terhitung sejak pelantikan dan sesudahnya dapat dipilih kembali dalam jabatannya dalam jabatan yang sama hanya untuk 1 kali masa jabatan. Kepala daerah sebelum memangku jabatannya akan terlebih dahulu dilantik dengan mengucapkan sumpah atau janji yang dipandu oleh pejabat yang melantik.

Pemerintah daerah dalam menyelengarakan pemerintahan daerah berpedoman pada asas penyelenggaraan pemerintahan negara sebagaimana yang diatur dalam Pasal 58 UndangUndang Pemerintahan Daerah, yaitu terdiri dari :

1) Asas kepastian hukum, yang dimaksud dengan asas kepastian hukum adalah asas dalam negara hukum yang mengutamakan landasan ketentuan peraturan perundang-undangan dan keadilan dalam setiap kebijakan penyelenggara negara.

2) Asas tertib penyelenggara negara, yang dimaksud dengan asas tertib penyelenggara negara adalah asas yang menjadi landasan keteraturan, keserasian, dan keseimbangan dalam pengendalian penyelenggara negara.

3) Asas kepentingan umum, yang dimaksud dengan asas kepentingan umum adalah asas yang mendahulukan kesejahteraan umum dengan cara yang aspiratif, akomodatif, dan selektif. 4) Asas keterbukaan, yang dimaksud dengan asas keterbukaan adalah asas yang membuka diri terhadap hak masyarakat yang memperoleh informasi yang benar, jujur, dan tidak diskriminatif tentang penyelenggaraan negara dengan tetap memperhatikan perlindungan atas hak asasi pribadi, golongan, dan rahasia negara.

5) Asas proporsionalitas, yang dimaksud dengan asas proporsionalitas adalah asas yang mengutamakan keseimbangan antara hak dan kewajiban penyelenggara negara.

6) Asas profesionalitas, yang dimaksud dengan asas profesionalitas adalah asas yang mengutamakan keahlian yang berlandaskan kode etik dan ketentuan peraturan perundangundangan.

7) Asas akuntabilitas, yang dimaksud dengan asas akuntabilitas adalah asas yang menentukan bahwa setiap kegiatan dan hasil akhir dari kegiatan penyelenggara negara harus dapat dipertanggungjawabkan kepada masyarakat atau rakyat sebagai pemegang kedaulatan tertinggi negara sesuai dengan ketentuan peraturan perundang-undangan. 
8) Asas efisiensi, yang dimaksud dengan asas efisiensi adalah asas yang berorientasi pada minimalisasi penggunaan sumber daya dalam penyelenggaraan negara untuk mencapai hasil kerja yang terbaik.

9) Asas efektivitas, yang dimaksud dengan asas efektivitas adalah asas yang berorientasi pada tujuan yang tepat guna dan berdaya guna.

10) Asas keadilan, yang dimaksud dengan asas keadilan adalah bahwa setiap tindakan dalam penyelenggaraan negara harus mencerminkan keadilan secara proporsional bagi setiap warga negara.

Pemerintah daerah merupakan kepala daerah sebagai unsur penyelenggara Pemerintahan Daerah yang memimpin pelaksanaan urusan pemerintahan yang menjadi kewenangan daerah otonom (Undang-Undang Nomor 23 Tahun 2014 tentang Pemerintah Daerah). Sedangkan Pemerintahan Daerah adalah penyelenggaraan urusan pemerintahan oleh pemerintah daerah dan Dewan Perwakilan Rakyat Daerah menurut asas otonomi dan tugas pembantuan dengan prinsip otonomi seluas-luasnya dalam sistem dan prinsip Negara Kesatuan Republik Indonesia sebagaimana dimaksud dalam Undang-Undang Dasar Negara Republik Indonesia Tahun 1945.

\section{KAJIAN TEORI}

\section{Gelar Adat}

Gelar adalah awalan (prefiks) atau akhiran (sufiks) yang ditambahkan pada nama seseorang untuk menandakan penghormatan, jabatan resmi, atau kualifikasi akademis atau profesional (https://id.wikipedia.org/wiki/Adat). Kamus umum Bahasa Indonesia karangan W.J.S Poerwadarminta maupun J.S Badudu dan Zain (Kamus Umum Bahasa Indonesia), gelar diartikan sebagai:

1) Kata yang ditambahkan pada nama seseorang untuk menunjukkan status atau martabat, seperti Raden, Tengku, Andi dan lain-lain. Gelar ini disebut juga gelar kebangsawanan, sedangkan gelar Sutan adalah gelar sesudah kawin bagi seorang pria.

2) Kata yang ditambahkan di depan atau di belakang nama seseorang yang telah berhasil menyelesaikan suatu jenjang studi di Perguruan Tinggi. Gelar ini dikenal sebagai gelar akademis atau title, seperti Drs, Dra, Ir, MM, M.Si, Dr, Profesor dan sebagainya. 
3) Nama alias

4) Nama yang diberikan orang berhubungan dengan keadaan badan atau tabi'at seseorang. Misalnya Bujang Dewo, Mat Pelor, Si Mulut Besar, Si Leher Beton dan sebagainya. Nama ini sebenarnya hanya berupa himbauan/panggilan, nama bukan sebenarnya.

5) Nama tambahan sebagai penghormatan menurut adat, baik yang bersifat turun temurun maupun yang melekat secara perorangan. Gelar ini dibedakan berdasarkan kesepakatan kelompok etnis yang bersangkutan atau kesepakatan dari kelompok organisasi atau Lembaga Adat Melayu menurut ico pakai tertentu, atas tugas jabatan tertentu pula, dilingkungan pemakai adat melayu yang bersangkutan. Gelar "Datuk" biasa dipakai sebagai sebutan karena status tertua dalam pertalian darah. Adapun gelar "Datuk" diberikan karena jabatan yang dituakan misalnya Datuk Pasirah, Datuk Penghulu.

Sedangkan konsep adat adalah gagasan kebudayaan yang terdiri dari nilai-nilai kebudayaan, norma, kebiasaan, kelembagaan, dan hukum adat yang lazim dilakukan di suatu daerah. Apabila adat ini tidak dilaksanakan akan terjadi kerancuan yang menimbulkan sanksi tak tertulis oleh masyarakat setempat terhadap pelaku yang dianggap menyimpang. Menurut Jalaluddin Tunsam (seorang yang berkebangsaan Arab yang tinggal di Aceh dalam tulisannya pada tahun 1660). "Adat" berasal dari bahasa Arab bentuk jamak dari (adah), yang berarti "cara", "kebiasaan". Di Indonesia, kata "adat" baru digunakan pada sekitar akhir abad 19. Sebelumnya kata ini hanya dikenal pada masyarakat Melayu setelah pertemuan budayanya dengan agama Islam pada sekitar abad 16-an. Kata ini antara lain dapat dibaca pada Undangundang Negeri Melayu (https://id.wikipedia.org/wiki/Adat).

\section{METODE PENELITIAN}

Penelitian ini akan dilaksanakan di Lembaga Adat Melayu Jambi Kabupaten Bungo. Mengenai Analis pemberian gelar adat kepada tokoh masyarakat oleh Lembaga Adat Melayu Jambi Kabupaten Bungo. Penelitian ini menggunakan metode penelitian kualitatif dengan cara melakukan pendekatan deskriptif, yaitu dengan bermaksud untuk mengetahui dan serta mendapatkan gambaran-gambaran tentang cara mengatasi permasalahan yang terjdi pada tempat dan waktu tertentu yang berkaitan dengan penelitian mengenai Analisis pemberian gelar adat kepada tokoh masyarakat oleh Lembaga Adat Melayu Jambi Kabupaten Bungo, 
kemudian berusaha untuk menganalisa dan serta menjelaskan proses pemberian gelaryang sebenarnya.

Penelitian deskriptif adalah merupakan metode penelitian yang mengumpulkan data berupa kata-kata, gambaran dan bukan angka-angka (Moelong, 2009:11). Istilah kualitatif sebagai prosedur penelitian yang menghasilkan data deskriptif berupa kata-kata tertulis atau lisan dari orang-orang dan perilaku yang diamati. Kirk dan miller menyatakan bahwa penelitian kualitatif adalah tradisi tertentu dalam ilmu pengetahuan sosial yang secara fundamental bergantung dari pengamatan pada manusia baik dalam kawasannya maupun dalam peristilahannya (Moelong, 2009:11).

\section{PEMBAHASAN}

Proses Pemberian Gelar Adat Kepada Kepala Daerah Kabupaten Bungo Sebagai Wujud Kesepakatan Sosial Etnis Melayu Bungo. Sebelum pada proses pemberian gelar adat kepada kepala daerah, adapun dasar pemberian gelar adat sebagai wujud kesepakatan sosial etnis adalah sebagai berikut. Pemberian gelar adat yang diberikan kepada kepala daerah merupakan hasil keputusan Rapat Kerja Daerah Lembaga Adat Melayu Kabupaten Bungo Nomor 01/LAD/2008 dan Nomor 12/KEP-LAM/2016, yang dituangkan dalam dalam program kerja tahunan :

1. Kepala daerah yang telah resmi memangku jabatan sebagai bupati atau wakil bupati Bungo, untuk itu Rapat Kerja Lembaga Adat Kabupaten Bungo telah sepakat memberikan gelar adat sesuai dengan Ico pakai "Jabatan dipangku, Gelar disandang". Pelaksanaan pengukuhan gelar adat dilaksanakan dalam suatu upacara bertempat dibalai Adat Melayu Kabupaten Bungo.

2. Lembaga Adat Melayu Kabupaten Bungo telah sepakat memberikan penghargaan Karang Setio terhadap pengurus Lembaga Adat Kabupaten Bungo dan Tokoh-tokoh Adat dalam Kabupaten Bungo atas jasa dan peran sertanya dalam melestarikan adat istiadat Melayu di Bumi Langkah Serentak Limbai Seayun Kabupaten Bungo.

3. Dengan begitu, agar seluruh program kerja tersebut terrealisasi, maka dibentuk Tim Penganugrahan Gelar Adat dan Penghargaan Karang Setio dengan Keputusan Lembaga Adat Melayu Kabupaten Bungo nomor 05/KEP-LAM/2009 tanggal 28 Desember 2009 yang hasilnya telah ditetapkan dengan Surat Keputusan Lembaga Adat Melayu Kabupaten Bungo (Buku Pedoman Adat Bungo, 2014: 22) . 
Rapat kerja Lembaga Adat Melayu Bungo yang berisi tentang Keputusan Lembaga Adat Melayu Kabupaten Bungo nomor 05/KEP-LAM/2009 tanggal 28 Desember 2009 yang hasilnya telah ditetapkan dengan Surat Keputusan Lembaga Adat Melayu Kabupaten Bungo merupakan suatu kebijakan. Heinz Eula dan Kenneth Prewit mendefenisikan kebijakan itu sebagai "keputusan tetap" yang dicirikan oleh konsistensi dan pengulangan (repetitiveness) tingkah laku dari merekayang membuat dan dari mereka yang mematuhi (Jones, 1994: 47). Roem topatimasang dkk, mendefinisikan kebijakan itu sebagai suatu sistem pembuatan, pelaksanaan, dan pengadilan keputusan-keputusan yang menyangkut kepentingan masyarakat luas (Topatimasang, 2000: 29). Charles E, Lindblom mengartikan kebijakan itu sebagai proses perumusan kebijaksanaan yang tidak teratur. Menurutnya kebijaksaan merupakan produk dari kebijakan (Lindblom, 1980:5). Kebijakan dalam konteks tersebut mengenai kesepakatan member gelar adat sesuai dengan surat keputrusan yang berlaku.

\section{Prosesi Pengukuhan dan Pemberian Gelar Adat}

Berbeda dengan dasar pemberian gelat adat yang merupakan hasil kesepakatan atau leputusan Lembaga Adat Melayu Kabupaten Bungo yang di tuangkan dalam Rapat Kerja Daerah Lembaga Adat. Dasar pelaksanaan Pembentukan Panitia Pengukuhan Gelar Adat, yaitu berdasarkan Keputusan Bupati Bungo Nomor 485/BPMPD/Tahun 2009 tanggal 28 Desember 2009 tentang Pembentukan Panitia Pengukuhan Gelar Adat dan bekerjasama dengan Lembaga Adat Melayu Kab.Bungo (Buku Panduan Pemberian Gelar Adat Kabupaten Bungo, 2010:32). Beberapa prosesi atau tata cara pemberian gelar adat kepada kepala daerah oleh Lembaga Adat Melayu Kab.Bungo, sebagai berikut :

1. Penjemputan dan Penyerahan

\section{a. Penunggu}

Proses pertama dari pengukuhan dan pemberian gelar adat kepada kepala daerah salah satunya yaitu proses penunggu, sekretaris Lembaga Adat Melayu Kabupaten Bungo mengatakan bahwa:

"Kepala daerah yang akan diberi gelar adat oleh Lembaga Adat Melayu Kab.Bungo didampingi oleh tuo-tuo tengganai sesepuh adat, istri, keluarga, pimpinan DPRD Kabupaten Bungo dan seluruh unsure Forkopimda Kabupaten Bungo di pendopo rumah Dinas Bupati Bungo dengan dilengkapi pelengkapan tapak sirih beserta anggotanya. Selain itu juga dikawal oleh dua orang pengawal adat yang memakai tombak dan paying bersilang empat yang ada dibalai adat (Rifai, 2019)”. 


\section{b. Penjemput}

"Nenek mamak, tuo-tuo tengganai menjemput Kepala daerah yang akan diberi gelar adat oleh Lembaga Adat Melayu Kab.Bungo didampingi oleh tuo-tuo tengganai sesepuh adat, istri, keluarga, pimpinan DPRD Kabupaten Bungo dan seluruh unsure Forkopimda Kabupaten Bungo di pendopo rumah Dinas Bupati Bungo menuju Balai Adat Melayu Kabupaten Bungo (Rifai, 2019).”

Menurut beliau, disaat proses penunggu dan penjemput didampingi dan dilakukan oleh beberapa anggota lembaga Adat Melayu. Karena prosesi ini merupakan hal yang sakral dan telah ditetapkan bersama.

Setelah tiba di balai adat, proses penyerahan gelar adat kepada kepala daerah dilanjutkan dengan berbagai kesenian, silat, kasidah, kompangan, pencanang atau liwa, pembacaan doa dan protocol prosesi.

Bertempat di balai adat pada waktu yang telah ditentukan, ketua Lembaga Adat Melayu Kabupaten Bungo berhadapan dengan nenek mamak yang telah dipersiapkan untuk melakukan penjemputan. Ketua Lembaga Adat Melayu Kabupaten Bungo akan melakukan peyambutan kepada kepala daerah yang dijemput, lalu menyampaikan rasa terimakasih kepada tuo-tuo tengganai serta ninik mamakn yang telah bersedia mengantar kepala daerah yang akan diberi gelar adat.

Sebagai tradisi melayu bungo, ketua lembaga adat kabupaten bungo menyerahkan buah tangan dalam bahasa adat yaitu cerano sirih sebuah, paying nan sekaki dan keperluan lainnya kepada nenek mamak, semua itu merupakan ucapan terima kasih dari pihak Lembaga Adat Melayu Kabupaten Bungo.

c. Setelah selesai acara penjemputan,

Maka secara bersama-sama-sama menuju Balai Adat dan dikawal oleh 2 buah mobil pengawal. Selanjutnya, tina di halaman balai adat kabupaten Bungo, kepala daerah tersebut beserta rombongan disambut dengan iringan kompangan dan robana.

Setelah beberapa langkah disambut dengan pencak silat dan tari melayu di atas plaza Balai Adat sambil memberikan salam sejahtera. Dalam proses ini, rombongan berjalan menuju Balai Adat sambil ditaburkan beras kuning, yang memiliki arti suatu kehormatan atas kedatangan rombongan. 
d. Proses di Balai Adat

Ketika sampai di Balai adat, kepala daerah beserta rombongan disambut oleh ketua Lembaga Adat Melayu Kabupaten Bungo dan kemudian diantar ke tempat yang telah dipersiapkan.

Sementara itu rombongan penjemput yang ada di Balai Adat menempatkan diri dari posisi sebelah kiri tempat pelaksanaan prosesi dan penunggu dari pendopo rumah dinas bupati Bungo, sesuai dengan tempat yang telah disediakan. Setelah itu juru bicara penjemput melaporkan kepada Ketua Lembaga Adat Melayu Kabupaten Bungo bahwa telah membawa bupati dan wakil bupati Bungo untuk diberi gelar Adat sesuai dengan kesepakatan sosial etnis melayu Bungo. Disinilah terjadi serah terima antara ninik mamak kepada Ketua Lembaga Adat Melayu Kabupaten Bungo. Setelah penyerahan berakhir ketua lembaga Adat Melayu Kabupaten Bungo mengantar Bupati dan wakil Bupati Bungo ke tempat duduk yang telah di sediakan. Upacara Pengukuhan Pemberian Gelar Adat

Upacara pengukuhan pemberian gelar adat Bungo merupakan kegiatan sakral dimulai dengan tertib acara :

1) Pembacaan ummul Quran.

2) Pembacaan kalam ilahi.

3) Laporan ketua panitia .

4) Pembacaan Surat Keputusan Lembaga Adat Melayu Kab.Bungo tentang Pemberian Gelar Adat kepada kepala daerah (Bupati/Wakil Bupati Bungo).

5) Prosesi pengukuhan pemberian gelar adat yang diawali dengan dengan kato pengukuhan.

6) Liwa atau Pengumunan.

7) Sambutan Ketua Lembaga Adat Melayu Kab.Bungo.

8) Sambutan Oleh sesepuh Adat Melayu Kab.Bungo.

9) Pembacaan Doa.

10) Ramah-tamah.

11) Acara selesai.

Naskah Pengukuhan pemberian gelar adat Bungo :

Dengan mengucapkan syukur kehadirat Allah, Tuhan yang maha kuasa. Pada hari iko (menyebutkan Hari/ Tanggal / Bulan / Tahun dalam bahasa Indonesia dan bulan Arab), sayo (menyebutkan nama dengan lengkap) sebagai Ketua Lembaga Adat Melayu Kab.Bungo, dengan iko resmi mengukuhkan gelar kebesaran Adat Melayu Kabupaten Bungo kepado : 
Bapak H. Mashuri., SP., ME

Dengan Gelar

Datuk Putro Arif Bijaksono Setioardjo

Dan

Safrudin Dwi Apriyanto., S.Pd

Dengan Gelar

Datuk Pemangku Setio Mandaliko

Sayo sisipkan pulo keris nan sabilah, tando kebesaran adat, jabatan dipangku gelar disandang, tinggi dianjung dengan sangseko, gedang diambak dengan lumbago, buat mareteh aka nanbajalin, mamancung unak nan bajumbal, mangkabung batang nan malintang dalam pergi membimbing anak negeri, berdasarkan surat keputusan lembaga adat melayu Kabupaten bungo 12/KEP-LAM/2016 (Buku Panduan Pemberian Gelar Adat Kabupaten Bungo, 2010: 29). Pemberian gelar adat kepada Kepala Daerah dianggap baik dalam berbagai aspek, salah satunya mengapresiasi putra/putri daerah yang menjadi pemimpin di daerahnya sendiri. Menurut salah satu akademisi yang ada di Kabupaten bungo, dalam wawancaranya menyampaikan sebagai berikut :

"Pemberian gelar adat melayu yang diberikan oleh Lembaga Adat Melayu Kab.Bungo kepada kepala daerah merupakan suatu tindakan yang dirasa baik. Dengan gelar adat yang diberikan secara tidak langsung memberikan apresiasi atau penghargaan kepada pemerintah atas nama masyarakat luas yang diwakilkan melalui Lembaga Adat Melayu Kabupaten Bungo. Selain itu, pemberian gelar tersebut tentunya tidak asal-asalan atau sembarangan. Tentunya atas dasar seloka ataupun tradisi yang telah ada terlebih dahulu, dengan begitu berarti Lembaga Adat Melayu Kab.Bungo secara tidak langsung telah melestarikan kebudayaan atau adat kebiasaan yang ada pada pemimpin terdahulu" (Novriansyah, 2019). Dari hasil wawancara yang dilakukan peneliti bersama salah satu Akademisi tersebut di dapat bahwa pemberian gelar adat kepada kepala daerah merupakan keputusan atau kebijakan yang diambil oleh Lembaga Adat Melayu Kabupaten Bungo yang bedasarkan beberapa pertimbangan seluko adat Melayu. Proses pemberian gelar adat juga tidak sembarangan, criteria gelar yang diberikan yaitu :

1. Gelar menggambarkan kepala daerah

2. Sesuai dengan ilmu yang dimilikinya

3. Mencerminkan kepribadian, karakter

4. Tidak boleh menghilangkan gelar (apabila memiliki gelar keturunan/sebagainya) 
Struktur-struktur Yang Mempengaruhi Dalam Pemberian Gelar Adat Kepada Kepala Daerah Kabupaten Bungo Lembaga Adat Melayu Jambi Kabupaten Bungo. Dalam pemberian gelar adat yang dikukuhkan oleh Lembaga Adat Melayu Kabupaten Bungo tentunya tidak terlepas dari beberapa peran yang mendukung berjalannya prosesi tersebut, seperti tim kecil yang bertugas merumuskan gelar yang hendak diberikan sampai para panitia pelaksanaan pemberian gelat adat dan juga rombongan yaitu fokopimda di Kabupaten Bungo.

Lembaga adat melayu Kabupaten Bungo, memiliki bebrapa struktur dan diketuai oleh H.Mahmud. AS sebagi ketua lembaga adat melayu kab.Bungo. struktur yang terlibat dalam perumusan gelar adat tidak seluruh dari pejabat atau anggota lembaga adat melayu Kab. Bungo. Namun hanya beberapa saja yang kemudian dibentuk lagi tim kecil atau tim khusus, berbeda saat rapat kerja daerah lembaga adat seluruh pejabat dan anggota ikut serta. Dalam pemilihan tim kecil atau khusus ini dipilih berdasarkan usulan dan keputusan bersama seluruh anggota Lembaga Adat Melayu Kab.Bungo. adapun dijelaskan saat wawancara sebagai berikut :

"Lembaga Adat Melayu Kabupaten Bungo Membentuk tim kecil atau tim khusus. Tim kecil atau tim khusus ini bertujuan untuk merumuskan nama atau gelar apa yang hendak diberikan kepada kepala daerah yang akan menerimanyan. Tim kecil atau tim khusus ini dalam merumuskan gelar tidak boleh sembarangan, karena gelar yang diberi haruslah sesuai dengan cerminan diri atau kepribadian, ilmunya, spesialis yang dimiliki, karakter maupun hal-hal yang berkaitan erat dengan kepala daerah tersebut. Tim kecil atau tim khusus ini biasanya berjumlah 17 pejabat Lembaga Adat Melayu Kab.Bungo yang terdiri dari 1 orang sebagai pepimpin tim kecil yaitu dipimpin langsung oleh ketua Lembaga Adat, 1 orang sekertris dan 15 pejabat sebagai anggota (Rifai, 2019).”

Dari wawancara dan diskusi tersebut, diketahui bahwa setelah tim kecil atau tim khusus menyelesaikan tugasnya dengan merumuskan gelar serta makna atau artinya yang hendak diberikan kepada kepala barulah di buat surat keputusan bersama untuk menyepakati hasil tersebut oleh seluruh pejabat structural lembaga adat Melayu Kabupaten Bungo.

\section{Dinas Pendidikan dan Kebudayaan Kabupaten Bungo}

Dinas Pendidikan dan Kebudayaan Kabupaten Bungo selaku dinas yang Melaksanakan Urusan Pemerintahan di Bidang Pendidikan dan Bidang Kebudayaan yang menjadi kewenangan Kota/Kabupaten dan Tugas Pembantuan yang diberikan kepada Kota maupun kabupaten. Dalam hal pemberian gelar adat melayu kabupaten Bungo, Dinas Pendidikan dan Kebudayaan Kabupaten Bungo tidak termasuk dalam tim kecil perumusan gelar. Dijelaskan 
saat wawancara dengan Kepala Dinas Pendidikan dan Kebudayaan Kabupaten Bungo sebagai berikut:

"Dinas Pendidikan dan Kebudayaan Kabupaten Bungo mengetahui adanya pemberian gelar yang diberikan kepada kepala daerah oleh Lembaga Adat Melayu Kab.Bungo, namun Dinas Pendidikan dan Kebudayaan Kabupaten Bungo tidak memiliki peran dalam perumusan gelar. Namun, saat pengukuhan atau acara pemberian Gelar yang diadakan di Balai adat Kab.Bungo tetap menghadari sebagai tamu saja (Masril, 2019)". Dari hasil wawancara penulis menyimpulkan bahwa tim kecil yang dibentuk oleh Lembaga Adat Melayu Kab.Bungo merupakan tim interen yang membahas dan menjalankan program kerja yang terdapat dalam RAKERDA Lembaga Adat Melayu Kab.Bungo. Sama halnya dengan Surat Keputusan Lembaga Adat Melayu Kab.Bungo yang membentuk panitia pemberian gelar adat kepada kepala daerah.

Kemudian kepala bidang (Kabid) Kebudayaan Kabupaten Bungo juga menyampaikan pada saat wawancara sebagai berikut :

"Pada saat pemberian gelar adat hanya sebagai tamu yang menghadiri dan juga belum menjabat sebagai kabid kebudayaan. Hal tersebut merupakan wewenanang dan ranah Lembaga adat Melayu Jambi Kabupaten Bungo sepenuhnya"

Jadi, dengan demikian Dinas Pendidikan dan Kebudayaan Kabupaten Bungo hanya sebagai tamu kehormatan saja dan tidak termasuk dalam anggota kepanitiaan, dan sepenuhnya dalam acara pemberian gelar adat melayu di urus oleh Lembaga Adat Melayu Kab.Bungo yang berlokasi di Balai Adat Melayu.

\section{Kendala-kendala Dalam Pelaksanaan Pemberian Gelar Adat}

Kendala-kendala atau hambatan oleh Lembaga Adat Melayu Kabupaten Bungo dalam pelaksanaan pemberian gelar adat ada beberapa, diantaranya yaitu :

1) Lembaga Adat Melayu Kabupaten Bungo terkendala dalam proses ceremony atau pengukuhan.

Dalam pelaksanaan atau pengukuhan pemberian gelar adat, Lembaga Adat Melayu Kabupaten Bungo terkendala masalah financial. Seperti wawancara dengan sekretaris Lembaga Adat Melayu Kab.Bungo sebagai berikut :

"Pemberian gelar adat kepada kepala daerah terkendala dengan besarnya dana yang dibutuhkan saat prosesi acara berlangsung. Dimana harus menyediakan 1 ekor kerbau yang nantinya kepala kerbau digunakan untuk penyerahan gelar sebagai simbolis dari ketua 
Lembaga Adat Melayu Kab.Bungo kepada Kepala Daerah. Sehingga, yang terjadi keterlambatan pemberian gelar yang idealnya diberikan sehari setelah kepala daerah terpilih tersebut dilantik, namun pada pelaksanaannya baru dapat di beri setelah beberapa bulan kepala daerah tersebut menjabat (Rifai, 2019).”

Dari hasil wawancara penulis mendapat kesimpulan dimana saat pengukuhan, membutuhkan kepala kerbau sebagai sebagai simbolis penyerahan gelar adat selain keris. Sehingga sering terjadi keterlambatan dalam penyerahan gelar adat.

2) Tidak keikutsertaan seluruh anggota Lembaga Adat Melayu Kabupaten Bungo Dalam Perumusan Gelar Adat.

Perumusan gelar hanya dibentuk oleh tim kecil yang dibuat oleh lembaga adat melayu kab.Bungo, dimana tidak semua anggota atau pejabat Lembaga Adat ikut serta. Hal tersebut menimbulkan pro dan kontra. Adapun wawancara peneliti bersama tokoh akademisi Kab.Bungo sebagai berikut :

"Ada beberapa oknum yang tidak sependapat dengan gelar yang disandang oleh kepala daerah yang telah diberikan oleh Lembaga Adat Melayu Kabupaten Bungo, di karenakan pada saat pemilihan kepala daerah atau bupati di Kabupaten bungo, ada beberapa oknum yang merupakan koalisi dan oposisi. Dimana saat telah terpilih dan hendak diberi gelar oknum yang oposisi beranggapan hal ini hanyalah sebuah permainan politik dari oknum koalisi. Pada kenyataannya, hal tesebut tidaklah benar. Karena pemberian gelar adat kepada kepala daerah sudah tertuang dalam rapat kerja daerah Lembaga Adat Melayu Kabupaten Bungo.”

Dari hasil wawancara bersama tokoh akademisi, peneliti dapat menyimpulkan hal tersebut terjadi karena kurangnya keterbukaan oleh Lembaga Adat Melayu Kabupaten.

3) Panduan atau pedoman pemberian gelar adat kepada kepala daerah belum di bukukan secara legal.

Kurangnya arsip serta buku terdahulu menjadi hambatan serta kendala dalam data. Sehingga terkadang saat ada keperluan data untuk dianalisa, menjadi terbatas akan data. Adapun wawancara dengan pengurus dan penjaga kantor Lembaga Adat Melayu Kabupaten Bungo sebagai berikut :

"Seperti saat ada mahasiwa ataupun lembaga lainnya yang membutuhkan data, arsip atau yang lain. Pengurus Lembaga Adat Melayu Kabupaten Bungo harus mencari file data di computer terlebih dahulu. Dikarenakan tidak dibukukan dan hanya file berbentuk software saja, seakan membuat tidak lengkapnya data. padahal seluruh data sudah ada namun tidak di arsipkan secara baik (Ahmad, 2019)." Berdasarkan hasil wawancara dengan pengurus Lembaga Adat Melayu Kabupaten Bungo, peneliti menyimpulkan kurangnya penulisan buku tentang sejarah Lembaga 
Adat Melayu Kabupaten Bungo untuk disebar luaskan kepada para masyarakat atau umum sebagai sumber ilmu pengetahuan.

\section{KESIMPULAN}

Berdasarkan hasil penelitian dan pembahasan yang telah ditentukan yaitu :

1. Pemberian gelar adat kepada kepala daerah oleh Lembaga Adat Melayu Kabupaten Bungo, disimpulkan :

a. Merupakan Rapat Kerja Daerah (Rakerda), Pemberian gelar adat yang diberikan kepada kepala daerah merupakan hasil keputusan Rapat Kerja Daerah Lembaga Adat Melayu Kabupaten Bungo Nomor 01/LAD/2008 dan Nomor 12/KEP-LAM/2016, yang dituangkan dalam dalam program kerja tahunan.

b. Surat Keputusan Lembaga Adat Melayu Kabupaten Bungo merupakan suatu kebijakan.

c. Dasar pelaksanaan Pembentukan Panitia Pengukuhan Gelar Adat, yaitu berdasarkan Keputusan Bupati Bungo Nomor 485/BPMPD/Tahun 2009 tanggal 28 Desember 2009 tentang Pembentukan Panitia Pengukuhan Gelar Adat dan bekerjasama dengan Lembaga Adat Melayu Kab.Bungo

2. Struktur-struktur yang mempengaruhi dalam pemberian gelar adat kepada kepala daerah Kabupaten Bungo, sepenuhnya diurus oleh Lembaga Adat Melayu Kab.Bungo.

3. Kendala-kendala Dalam Pelaksanaan Pemberian Gelar Adat

a) Lembaga Adat Melayu Kabupaten Bungo terkendala dalam proses ceremony atau pengukuhan karena financial.

b) Tidak keikutsertaan seluruh anggota Lembaga Adat Melayu Kabupaten Bungo Dalam Perumusan Gelar Adat.

c) Panduan atau pedoman pemberian gelar adat kepada kepala daerah belum di bukukan secara legal.

\section{DAFTAR PUSTAKA}

Buku Pedoman Adat Bungo. 2014. Lembaga adat bungo, Muara Bungo.

Charles E, Lindblom. 1980. Proses Penetapan Kebijakan. Jakarta: Erlangga.

Charles O, Jones. Pengantar Kebijakan Publik (Public Policy). 1994. Jakarta: Rajawali Press. http://informasijambi.blogspot.com/2010/03/apa-itu-lembaga-adat.html 
https://id.wikipedia.org/wiki/Adat, diakses pada hari minggu tanggal 20 Januari pukul 00.55 wib

https://id.wikipedia.org/wiki/Jenis_gelar di akses pada hari sabtu tanggal 23 maret 2019 pukul01.26

Kamus umum Bahasa Indonesia karangan W.J.S Poerwadarminta maupun J.S Badudu dan Zain.

Lexy. J. Meleong, 2009. Metode Penelitian Kualitatif. Bandung : Remaja Rosdakarya.

Roem topatimasang dkk. 2009. Merubah Kebijakan Publik. Yogyakarta: Pustaka Pelajar.

Suminto Aqib. H.DR. 1986. Politik Islam Hindia Belanda. Jakarta: LP3ES.

Undang-Undang Nomor 23 Tahun 2014 tentang Pemerintah Daerah.

Wawancara dengan Drs.H.M Rifai., Abtes.Sy, Selasa pagi tanggal 9 April 2019.

Wawancara dengan Drs.H.M Rifai., Abtes.Sy, Selasa pagi tanggal 9 April 2019.

Wawancara dengan Yudi novriansyah., Sos. M.Si.

Wawancara dengan Masril.

Wawancara dengan nurdin ahmda. Pada hari senin 15 April 2019. 